\title{
Factors associated with career satisfaction and burnout among US neurosurgeons: results of a nationwide survey
}

\author{
Joseph H. McAbee, BS, ${ }^{1}$ Brian T. Ragel, MD, ${ }^{2}$ Shirley McCartney, PhD, ${ }^{2}$ G. Morgan Jones, PharmD, \\ BCPS, ${ }^{3,4,5}$ L. Madison Michael II, MD, ${ }^{3,6}$ Michael DeCuypere, MD, PhD, ${ }^{3}$ Joseph S. Cheng, MD, MS, \\ Frederick A. Boop, MD, ,3,6,8 and Paul Klimo Jr., MD, MPH $3,6,8$
}

\begin{abstract}
${ }^{1}$ School of Medicine, Wake Forest University, Winston-Salem, North Carolina; '2Department of Neurological Surgery, Oregon Health \& Science University, Portland, Oregon; Departments of ${ }^{3}$ Neurosurgery, ${ }^{4}$ Neurology, and ${ }^{5}$ Clinical Pharmacy, University of Tennessee Health Science Center; ${ }^{6}$ Semmes-Murphey Neurologic \& Spine Institute; ${ }^{8}$ Le Bonheur Neuroscience Institute, Le Bonheur Children's Hospital, Memphis; and 'Department of Neurosurgery, Vanderbilt University Medical Center, Nashville, Tennessee
\end{abstract}
OBJECT The object of this study was to identify and quantify predictors of burnout and career satisfaction among US neurosurgeons.

METHODS All US members (3247) of the American Association of Neurological Surgeons (AANS) were invited to participate in a survey between September and December 2012. Responses were evaluated through univariate analysis. Factors independently associated with burnout and career satisfaction were determined using multivariable logistic regression. Subgroup analysis of academic and nonacademic neurosurgeons was performed as well.

RESULTS The survey response rate was $24 \%$ (783 members). The majority of respondents were male, 40-60 years old, in a stable relationship, with children, working in a group or university practice, and trained in a subspecialty. More than $80 \%$ of respondents reported being at least somewhat satisfied with their career, and $70 \%$ would choose a career in neurosurgery again; however, only $26 \%$ of neurosurgeons believed their professional lives would improve in the future, and $52 \%$ believed it would worsen. The overall burnout rate was $56.7 \%$. Factors independently associated with both burnout and career satisfaction included achieving a balance between work and life outside the hospital (burnout OR 0.45 , satisfaction OR 10.0) and anxiety over future earnings and/or health care reform (burnout OR 1.96, satisfaction OR 0.32). While the burnout rate for nonacademic neurosurgeons $(62.9 \%)$ was higher than that for academic neurosurgeons $(47.7 \%)$, academicians who had practiced for over 20 years were less likely to be satisfied with their careers.

CONCLUSIONS The rates of burnout and career satisfaction were both high in this survey study of US neurosurgeons. The negative effects of burnout on the lives of surgeons, patients, and their families require further study and probably necessitate the development of interventional programs at local, regional, and even national levels.

http://thejns.org/doi/abs/10.3171/2014.12.JNS141348

KEY WORDS neurosurgery; burnout; career; satisfaction; survey; health care reform

$\mathrm{M}$ EDICINE combines scientific discovery with the opportunity to care for patients with a diverse range of disease. Physicians, however, are subject to a number of stressors and challenges that may lead to an unhealthy level of dissatisfaction, and even burnout. "Burnout" has been defined as a clinical syndrome characterized by emotional exhaustion, depersonalization, and a decreased sense of accomplishment. ${ }^{9}$ A definition of burnout is included in the International Statistical Classification of Diseases and Related Health Problems 10th Revision (ICD-10 Version:2010, http://apps.who.int/classifications/ icd10) as a drawback related to life-management difficulty combined with a state of vital exhaustion. Symptoms include fatigue, poor judgment, cynicism, guilt, feelings of ineffectiveness, and disconnection with coworkers or patients. ${ }^{1,9,34}$ Maslach et al. defined burnout among health care providers as a psychological process whereby human service professionals attempting to positively impact the lives of others become overwhelmed and frustrated by unforeseen stressors related to their jobs. ${ }^{30}$

Burnout and dissatisfaction with one's career are pervasive problems in medicine that can negatively affect a phy-

ABBREVIATIONS AANS = American Association of Neurological Surgeons; $A U C=$ area under the curve; $C S N S=$ Council of State Neurosurgical Societies; $M B I=$ Maslach Burnout Inventory; PPACA = Patient Protection and Affordable Care Act.

SUBMITTED June 17, 2014. ACCEPTED December 15, 2014.

INCLUDE WHEN CITING Published online February 13, 2015; DOI: 10.3171/2014.12.JNS141348.

DISCLOSURE The authors report no conflict of interest concerning the materials or methods used in this study or the findings specified in this paper. 
sician's personal, physical, and mental well-being. They are associated with interpersonal relationship dysfunction, substance abuse, suicidal ideation, and a desire by young surgeons to retire early. ${ }^{2,11,35}$ More medical errors have also been reported among surgeons who experience higher levels of burnout. ${ }^{36,47,48}$ Patients who are treated by physicians suffering from burnout are more often dissatisfied with their level of care and are more likely to participate in malpractice suits. ${ }^{2}$

Many studies have gauged the level of burnout in various medical subspecialties. In a landmark study, Shanafelt and colleagues surveyed 7905 surgeons in an effort to identify personal and professional characteristics that may predict burnout. ${ }^{37}$ They found that specialty practice area, ${ }^{7}$ number of nights on call per week, ${ }^{5}$ hours worked per week, ${ }^{5}$ younger age, ${ }^{25}$ and compensation based entirely on billing were factors associated with surgeon burnout. ${ }^{37}$ Further studies report that surgeons who are female, ${ }^{16}$ work in private practice, ${ }^{7}$ or report not having enough time for family or personal life ${ }^{4,38}$ have higher levels of burnout. Conversely, surgeons who are older, ${ }^{25}$ work in academia, ${ }^{7}$ have sufficient time for non-patient care activities, ${ }^{6,25}$ and spend more time in the operating room $^{37}$ are typically more satisfied with their career choice.

While previous studies have included a small sample of neurosurgeons, there is little research dedicated to career satisfaction or burnout in what is arguably one of the most intense fields in medicine. We recently published our results from a pilot study in which 85 neurosurgeons completed a 107-item questionnaire. ${ }^{23}$ After partnering with the Council of State Neurosurgical Societies (CSNS), we conducted a nationwide study using a modified and shortened version of our original questionnaire. The primary objective of this study was to better define within neurosurgery the level of burnout and career satisfaction and their predictive factors.

\section{Methods}

A shorter, modified online version (SurveyMonkey) of the pilot study questionnaire was used to improve participation (Appendix). An e-invitation to complete the survey was sent to all US members of the American Association of Neurological Surgeons (AANS) on behalf of the CSNS on 4 separate occasions between September and December 2012. Electronic communication to potential survey respondents included a link to the survey, as well as a cover letter outlining the purpose of the survey. Participation was voluntary and data were de-identified by the survey administrator (S.M.) prior to analysis. We combined responses from this survey with those from our previous pilot study as we assumed that those neurosurgeons who participated in the pilot survey were not likely to complete the updated survey.

\section{Definitions and Statistical Analysis}

Descriptive summary statistics were used to describe the overall group of respondents. Select survey responses were combined into categories for the purposes of statistical analysis based on previous literature and number of responses within the original selections. All categories were determined prior to completing any statistical analysis. For example, responses to specific questions regarding professional perceptions that were believed to have a large impact on the desired outcome were converted from a Likert-type scale to dichotomous variables. The number of age categories was collapsed from 7 to 3 to approximate the early (up to and including age 45 years), middle (46-55 years), and later ( $>55$ years) stages of a person's career, with each stage selected to represent an approximate 10year period.

We decided a priori to identify and quantify predictors of 2 survey outcomes: 1) burnout and 2) career satisfaction. Burnout was measured using the validated Maslach Burnout Inventory (MBI) that assesses emotional exhaustion (9 questions), depersonalization (5 questions), and personal accomplishment (8 questions). Using the same definition as Shanafelt et al. and the cutoff values specific for those who work in medicine as set forth in the MBI manual, burnout was defined as having high scores for emotional exhaustion or depersonalization on the MBI. ${ }^{30,37}$ Respondents were classified as being satisfied with their career if they selected "very satisfied" or "somewhat satisfied" on Question 1 of the professional satisfaction section of the survey. Subgroup analysis evaluating the same outcomes in respondents who described their job as "academic" versus those who did not was also performed.

After conducting univariate analysis, forward multivariable logistic regression was undertaken to assess independent associations related to the dichotomous variables of burnout and career satisfaction. Variables with $p<0.2$ in the univariate analysis were placed in the logistic regression model initially. The same methodology was used for the subgroup analysis of academic and nonacademic neurosurgeons. Two-tailed statistical tests were performed, and $\mathrm{p} \leq 0.05$ was determined to represent statistical significance in the univariate and multivariable analysis. The level of statistical significance for multiple comparisons was not adjusted. Results were reported as adjusted odds ratio with corresponding 95\% confidence intervals. All data were analyzed using SPSS software (IBM SPSS Statistics for Windows, Version 21.0, Released 2012, IBM Corp.).

\section{Results}

\section{Survey Results}

Of the 3247 US neurosurgeons invited to complete the survey, 783 responded (24\%). Responses from 33 physicians were excluded due to incompleteness on the 22-question MBI, yielding 750 completed surveys.

The majority of respondents were male, between the ages of 40 and 60 years, in a stable relationship with children, and working in a group or university practice with subspecialty training. Most worked more than 50 hours per week, took call 6 or more days per month, and completed over 200 cases annually. Just over half indicated that they had not been involved in any malpractice suits over the last 5 years (2008-2012). A detailed summary of personal and practice characteristics of the 750 survey participants is provided in Table 1.

A breakdown of responses for the survey sections on 
TABLE 1. Demographic information on 750 survey respondents

\begin{tabular}{|c|c|}
\hline Characteristic & No. $(\%)$ \\
\hline Male & $655(87.3)$ \\
\hline \multicolumn{2}{|l|}{ Age (yrs) } \\
\hline$\leq 40$ & $90(12.0)$ \\
\hline $41-45$ & $142(18.9)$ \\
\hline $46-50$ & $135(18.0)$ \\
\hline $51-55$ & $145(19.3)$ \\
\hline $56-60$ & $121(16.1)$ \\
\hline $61-65$ & $74(9.9)$ \\
\hline$>65$ & $43(5.7)$ \\
\hline \multicolumn{2}{|l|}{ Relationship status } \\
\hline Stable partner/married & $683(91.1)$ \\
\hline Single & $67(8.9)$ \\
\hline Divorced* & $68(9.1)$ \\
\hline Children & $667(88.9)$ \\
\hline \multicolumn{2}{|l|}{ Practice type } \\
\hline Group & $286(38.1)$ \\
\hline University & $191(25.5)$ \\
\hline Private $w /$ academic affiliation & $114(15.2)$ \\
\hline Solo & $94(12.5)$ \\
\hline Other & $42(5.6)$ \\
\hline Health care management organization & $12(1.6)$ \\
\hline Veterans Affairs/government & $11(1.5)$ \\
\hline Academic/university affiliation & $308(41.1)$ \\
\hline \multicolumn{2}{|l|}{ Duration of practice (yrs) } \\
\hline$<5$ & $73(9.7)$ \\
\hline $5-10$ & $121(16.1)$ \\
\hline $11-15$ & $153(20.4)$ \\
\hline $16-20$ & $117(15.6)$ \\
\hline $20-25$ & $124(16.5)$ \\
\hline$>25$ & $162(21.6)$ \\
\hline Any subspecialty training & $418(55.7)$ \\
\hline Spine & $132(17.6)$ \\
\hline Pediatrics & $76(10.1)$ \\
\hline Cerebrovascular & $55(7.3)$ \\
\hline Skull base & $58(7.7)$ \\
\hline Functional \& stereotactic & $44(5.9)$ \\
\hline Other & $53(7.1)$ \\
\hline \multicolumn{2}{|l|}{ Hours worked per week } \\
\hline$<40$ & $15(2.0)$ \\
\hline $41-50$ & $83(11.1)$ \\
\hline $51-60$ & $202(26.9)$ \\
\hline $61-70$ & $242(32.3)$ \\
\hline $71-80$ & $106(14.1)$ \\
\hline$>80$ & $102(13.6)$ \\
\hline \multicolumn{2}{|l|}{ On-call days per month } \\
\hline$<3$ & $60(8.0)$ \\
\hline $3-5$ & $129(17.2)$ \\
\hline $6-10$ & $333(44.4)$ \\
\hline$>10$ & $228(30.4)$ \\
\hline
\end{tabular}

TABLE 1. Demographic information on 750 survey respondents (continued)

\begin{tabular}{lc}
\hline \multicolumn{1}{c}{ Characteristic } & No. $(\%)$ \\
\hline Cases completed annually & \\
\hline$<200$ & $221(29.5)$ \\
\hline $201-300$ & $312(41.6)$ \\
\hline $301-400$ & $160(21.3)$ \\
\hline$>400$ & $57(7.6)$ \\
\hline Malpractice cases over the last 5 yrs (2008-2012) \\
\hline 0 & $407(54.3)$ \\
\hline $1-5$ & $333(44.4)$ \\
\hline$>5$ & $10(1.3)$ \\
\hline
\end{tabular}

* Percentage of total population $(n=750)$ who stated they had been through a divorce during career.

professional stressors, satisfaction, and quality of life is shown in Figs. 1-3. Too much call (59.2\%), uncertainty about future earnings/health care reform (75.2\%), inadequate administration time (46.9\%), low salary (48.8\%), and too little vacation time (43.7\%) had at least a moderate impact on neurosurgeons' professional careers (Fig. 1). Participants were satisfied with the location of their practice $(75.1 \%)$ and their neurosurgical colleagues $(65.1 \%)$, but were dissatisfied with the time allowed for personal growth/development (44.6\%) and believed that reimbursement should be improved (69.6\%; Figs. 2 and 3).

Selected questions from each of the 3 sections-professional stressors, satisfaction, and quality of life-and from the general questions section of the survey are shown in Table 2. More than $80 \%$ cited that they were satisfied with their career as a neurosurgeon. Strong responses by participants included being intellectually challenged by their work (77.3\%), having a spouse that understood their demanding work schedule (73.5\%), and being concerned about future earnings and health care reform (53.5\%).

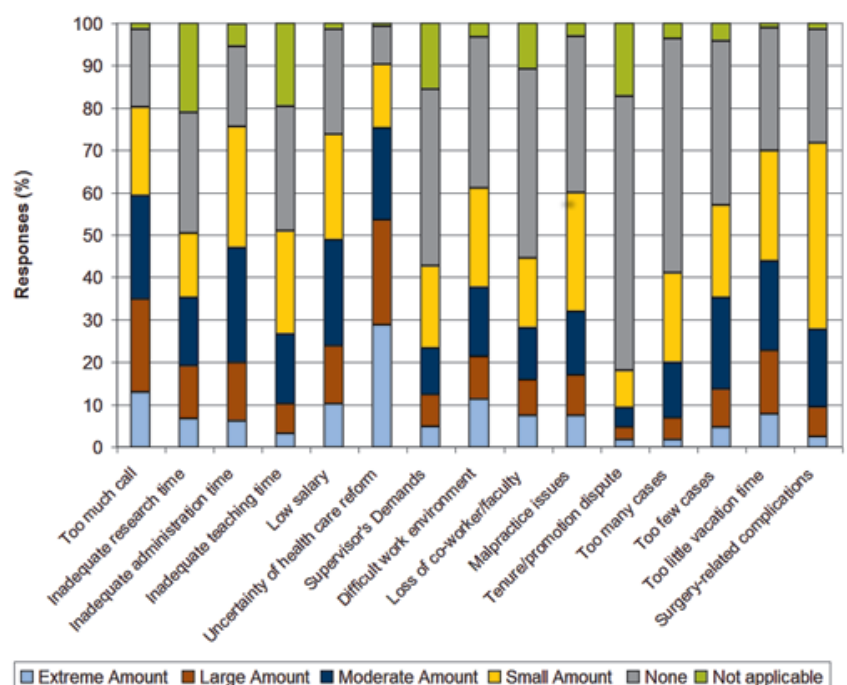

FIG. 1. Response to questions for Professional Stressors (Appendix, Section 2). Figure is available in color online only. 


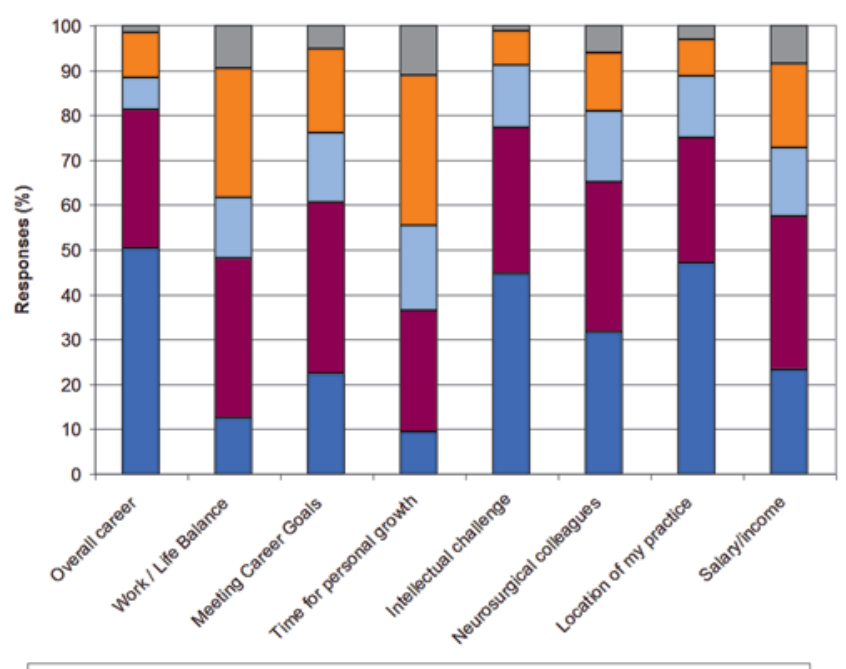

घ Very Satisfied $\square$ Somewhat Satisfied $\square$ Neutral $\square$ Somewhat Dissatisfied $\square$ Very Dissatisfied

FIG. 2. Response to questions for Professional Satisfaction (Appendix, Section 3). Figure is available in color online only.

Only $36.5 \%$ believed that they had adequate time for personal growth/development, and $48.1 \%$ had achieved a balance between work and life. Although almost $70 \%$ of respondents would choose a career in neurosurgery again, only $35.5 \%$ would recommend neurosurgery as a career to their children.

When asked if they felt their professional life would improve, only $26 \%$ of neurosurgeons agreed. Moreover, when asked if they felt their professional life would worsen, $52 \%$ agreed, whereas only $24.8 \%$ did not. The direction neurosurgeons believe their careers will take in the future is depicted graphically in Fig. 4.

The burnout rate overall was $56.7 \%$ (Table 3). High emotional exhaustion was reported in $35.1 \%$ of neurosurgeons, high depersonalization in $31.3 \%$, and a low sense of personal accomplishment in $28.4 \%$.

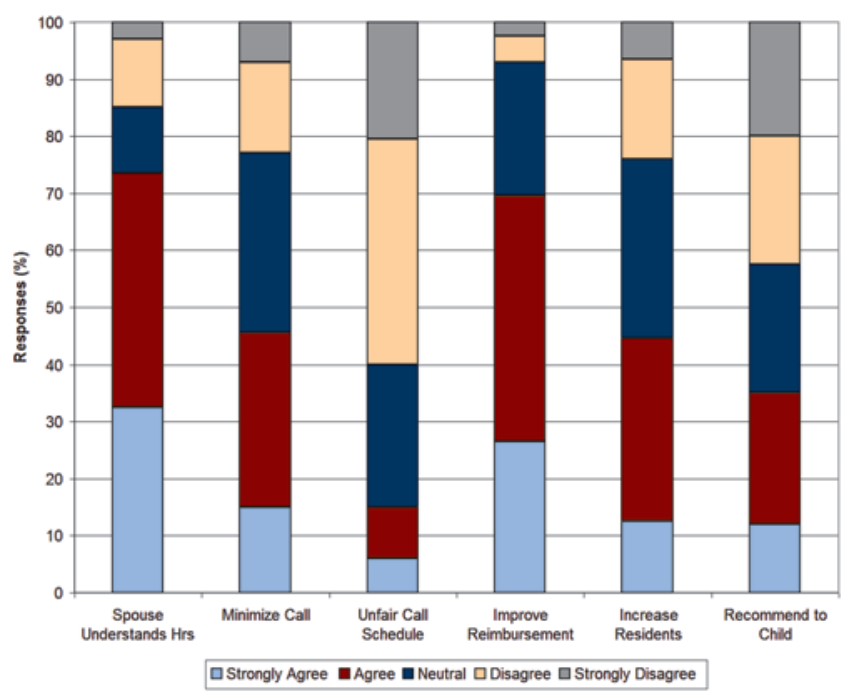

FIG. 3. Response to questions for Quality of Professional Life (Appendix, Section 4). Figure is available in color online only.
TABLE 2. Professional perceptions among surveyed neurosurgeons

\begin{tabular}{|c|c|}
\hline Perception & No. $(\%)$ \\
\hline Satisfied w/ career as a neurosurgeon* & $609(81.2)$ \\
\hline Adequate time for personal development $†$ & $274(36.5)$ \\
\hline Challenged at work $\dagger$ & $580(77.3)$ \\
\hline Good work/life balance $†$ & $361(48.1)$ \\
\hline Spouse understands when they work extra hours $†$ & $551(73.5)$ \\
\hline Would choose to be a neurosurgeon again $\dagger$ & $512(68.3)$ \\
\hline $\begin{array}{l}\text { Would recommend neurosurgery as a career to } \\
\text { their childrent }\end{array}$ & $266(35.5)$ \\
\hline Uncertain of future earnings/health care reform $\ddagger$ & $401(53.5)$ \\
\hline \multicolumn{2}{|c|}{$\begin{array}{l}\text { * Respondents answered "very satisfied" or "somewhat satisfied" with the } \\
\text { factors surveyed. } \\
\text { † Respondents answered "strongly agree" or "agree" that they were satisfied } \\
\text { with the factors surveyed. } \\
\text { † Respondents answered that the factors surveyed impact their practice to an } \\
\text { "extreme amount" or a "large amount." }\end{array}$} \\
\hline
\end{tabular}

\section{Predictors of Satisfaction and Burnout}

The results of univariate analysis are shown in Table 4. Factors that were independently associated with career satisfaction and burnout are listed in Table 5. Six factors were predictive of burnout and 7 for career satisfaction. Being accused of malpractice (OR 1.6) and having uncertainty regarding future earnings/health care reform (OR 1.96) significantly increased the odds of being burned out, while 4 other practice characteristics or perceptions were protective. Four of the 7 factors independently associated with career satisfaction were positive correlations, including having children (OR 2.4) and a good work/life balance (OR 10.0). Achieving a balance between work and life and anxiety over future earnings/health care reform were factors shown to significantly impact the odds of both outcomes. The presence of burnout reduced the odds of being satisfied with one's career almost 6-fold (OR 0.17).

\section{Academic Versus Nonacademic Neurosurgeons}

Characteristics of academic and nonacademic neurosurgeons are shown in Table 6 . Variables that were independently associated with career satisfaction and burnout among academic and nonacademic neurosurgeons are shown in Tables 7 and 8, respectively.

\section{Discussion}

\section{Study Findings}

Neurosurgery has been-and will remain-a stressful yet rewarding profession. This survey study represents the most comprehensive attempt to identify and quantify sources of satisfaction and burnout in neurosurgeons. Among all survey participants, factors shown to independently increase the odds of being satisfied with a career in neurosurgery included being surgically productive, having children, being intellectually stimulated, and achieving balance between career and life outside of work. The burnout rate overall was $56.7 \%$ (35.1\% emotional exhaustion and $31.3 \%$ depersonalization), which is 


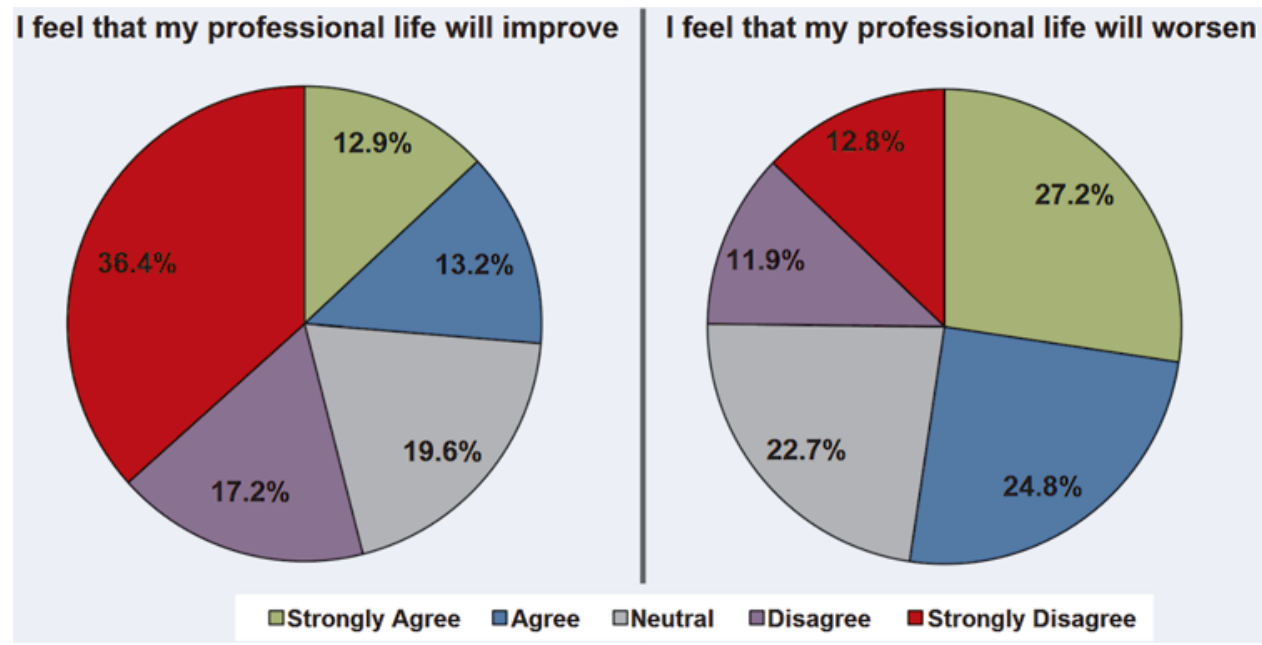

FIG. 4. Perceptions among neurosurgeons on the future direction of their career. Figure is available in color online only.

one of the highest reported rates among surgical ${ }^{8,25,33,37,44,45}$ and nonsurgical specialties, ${ }^{10,13,14,26,27,31,32,40}$ including those in previously published reports for neurosurgeons (Table 9) ${ }^{7,23,37}$ Burnout was associated with malpractice litigation and uncertainty regarding future earnings and health care reform, which was also shown to decrease the odds of being satisfied with neurosurgery.

\section{Burnout}

The study of burnout and career satisfaction is immensely important in today's health care system with effects that permeate many different aspects of health care delivery. Physician burnout has been shown to lead to medical errors, ${ }^{19,36,39,47,48}$ early retirement, ${ }^{11,22,43}$ diminished patient satisfaction with care, ${ }^{20,28}$ and increased malpractice suits. ${ }^{21}$ Surgeons from every specialty are at very high risk for burnout., ${ }^{77}$ The current study and prior pilot study are the only studies, to our knowledge, that have been designed specifically to garner feedback from neurosurgeons. Despite a high burnout rate among the neurosurgeons who participated in the survey, the overall career satisfaction response rate was $81.2 \%$. Similar studies have found this seemingly paradoxical finding, ${ }^{7,25}$ which supports the innate subjectivity of burnout assessment. Burnout can occur in transient or periodic episodes, thus causing physicians to suffer from burnout at some point in their career while still being satisfied overall. Interestingly, a physician's perception of his or her own life seems to play a significant role in the relative impact of burnout on career satisfaction.

\section{Sources of Satisfaction and Dissatisfaction}

In almost all models for satisfaction and burnout, neurosurgeons have indicated that they enjoy being challenged at work. The data presented suggest that neurosurgeons are content when they are in the early-to-middle portion of their career, are consistently challenged, and spend considerable time in the operating room. In a previous crosssectional study, Dyrbye and colleagues examined how the stage in a physician's career affects burnout and satisfac- tion. ${ }^{17}$ Physicians from all specialties in the US were analyzed and showed that the lowest satisfaction occurs at 2 times during their careers. First, during the early stages of their careers, physicians were dissatisfied with their overall career choice (that is, being a physician) because of work/home conflicts and feelings of depersonalization. Second, during the midstages of their careers, they were dissatisfied with their specialty career choice because of excessive work demands (that is, working long hours and taking overnight call). ${ }^{17}$ This finding is contrary to data in the current study. We hypothesize that the typical neurosurgeon experiences excitement and energy in practicing independently during the early part of their career and then may achieve a "professional peak" in terms of skill level, experience, or impact during the middle portion of their career. It is reasonable to infer that the latter stage of their career may be negatively affected by greater admin-

TABLE 3. Burnout indices among 750 neurosurgeons*

\begin{tabular}{ccc}
\hline Burnout Indices & Median Score (IQR) & No. $(\%)$ \\
\hline Emotional exhaustion & $21(11-31)$ & - \\
\hline Low score $(\leq 18)$ & - & $322(42.9)$ \\
\hline Moderate score & - & $165(22.0)$ \\
\hline High score $(\geq 27)$ & - & $263(35.1)$ \\
\hline Depersonalization & $6(3-11)$ & - \\
\hline Low score $(\leq 5)$ & - & $349(46.5)$ \\
\hline Moderate score & - & $166(22.1)$ \\
\hline High score $(\geq 10)$ & - & $235(31.3)$ \\
\hline Personal accomplishment & $38(31-43)$ & - \\
\hline Low score $(\leq 33)$ & - & $312(28.4)$ \\
\hline Moderate score & - & $201(26.8)$ \\
\hline High score $(\geq 40)$ & - & $336(44.8)$ \\
\hline Burned out $\dagger$ & - & $425(56.7)$ \\
\hline
\end{tabular}

* All data are listed as median ( $25 \%-75 \%$ interquartile range [IQR]) unless otherwise noted.

† High score on emotional exhaustion and/or depersonalization subscales (see Methods). 
TABLE 4. Univariate analysis of burnout and satisfaction among neurosurgeons

\begin{tabular}{|c|c|c|c|c|c|c|}
\hline \multirow[b]{3}{*}{ Characteristic } & \multicolumn{6}{|c|}{ No. (\%) } \\
\hline & \multicolumn{3}{|c|}{ Satisfied } & \multicolumn{3}{|c|}{ Burned Out } \\
\hline & No & Yes & $p$ Value & No & Yes & p Value \\
\hline No. of respondents & 141 & 609 & & 325 & 425 & \\
\hline \multicolumn{7}{|l|}{ Age (yrs) } \\
\hline$<45$ & $48(34.0)$ & $184(30.2)$ & 0.38 & $96(29.5)$ & $136(32.0)$ & 0.47 \\
\hline $46-55$ & $48(34.0)$ & $232(38.1)$ & 0.37 & $130(40.0)$ & $150(35.3)$ & 0.19 \\
\hline$>55$ & $45(31.9)$ & $193(31.7)$ & 0.96 & $99(30.5)$ & $139(32.7)$ & 0.51 \\
\hline Female & $26(18.4)$ & $68(11.2)$ & 0.019 & $32(9.8)$ & $62(14.6)$ & 0.052 \\
\hline \multicolumn{7}{|l|}{ Relationship status } \\
\hline Stable relationship/married & - & - & - & $299(92.0)$ & $384(90.4)$ & 0.43 \\
\hline Single & - & - & - & $26(8.0)$ & $41(9.6)$ & 0.43 \\
\hline Children & $116(82.3)$ & $551(90.5)$ & 0.005 & $295(90.8)$ & $372(87.5)$ & 0.16 \\
\hline Academic affiliation & $41(29.1)$ & $267(43.8)$ & 0.001 & $161(49.5)$ & $147(34.6)$ & $<0.001$ \\
\hline \multicolumn{7}{|l|}{ Career duration } \\
\hline$\leq 10 \mathrm{yrs}$ & $32(22.7)$ & $162(26.6)$ & 0.34 & $82(25.2)$ & $112(26.4)$ & 0.73 \\
\hline $11-20$ yrs & $44(31.2)$ & $226(37.1)$ & 0.19 & $120(36.9)$ & $150(35.3)$ & 0.65 \\
\hline$>20 \mathrm{yrs}$ & $65(46.1)$ & $221(36.3)$ & 0.03 & $123(37.8)$ & $163(38.4)$ & 0.89 \\
\hline Subspecialty training & $66(46.8)$ & $353(58.0)$ & 0.02 & $190(58.5)$ & $229(53.9)$ & 0.21 \\
\hline Cerebrovascular & $7(5.0)$ & $47(7.7)$ & 0.25 & $25(7.7)$ & $29(6.8)$ & 0.65 \\
\hline Functional/stereotactic & $7(5.0)$ & $37(6.1)$ & 0.61 & $24(7.4)$ & $20(4.7)$ & 0.12 \\
\hline Pediatrics & $7(5.0)$ & $69(11.3)$ & 0.02 & $37(11.4)$ & $39(9.2)$ & 0.32 \\
\hline Spine & $24(17.0)$ & $109(17.9)$ & 0.81 & $56(17.2)$ & 77 (18.1) & 0.75 \\
\hline Skull base & $12(8.5)$ & $46(7.6)$ & 0.70 & $26(8.0)$ & $32(7.5)$ & 0.81 \\
\hline Other & $9(6.4)$ & $45(7.4)$ & 0.26 & $22(6.8)$ & $31(7.3)$ & 0.77 \\
\hline \multicolumn{7}{|l|}{ Productivity } \\
\hline On call >10 days/mo & $48(34.0)$ & $180(29.6)$ & 0.30 & $92(28.3)$ & $136(32.0)$ & 0.28 \\
\hline Performs >300 cases/yr & $29(20.6)$ & $188(30.9)$ & 0.015 & $100(30.8)$ & $117(27.5)$ & 0.33 \\
\hline Work $>70 \mathrm{hrs} / \mathrm{wk}$ & $36(25.5)$ & $173(28.4)$ & 0.49 & $89(27.4)$ & $120(28.2)$ & 0.80 \\
\hline Accused of malpractice & $70(49.6)$ & $273(44.8)$ & 0.30 & $121(37.2)$ & $222(52.2)$ & $<0.001$ \\
\hline \multicolumn{7}{|l|}{ Professional perceptions } \\
\hline Adequate time for personal development & $7(5.0)$ & $267(43.8)$ & $<0.001$ & $174(53.5)$ & $100(23.5)$ & $<0.001$ \\
\hline Challenged at work & $62(44.0)$ & $518(85.1)$ & $<0.001$ & $284(87.4)$ & $296(69.6)$ & $<0.001$ \\
\hline Good work/life balance & $10(7.1)$ & $351(57.6)$ & $<0.001$ & $216(66.5)$ & $145(34.1)$ & $<0.001$ \\
\hline Spouse understands extra work hrs & $91(64.5)$ & $460(75.5)$ & 0.008 & $259(79.7)$ & $292(68.7)$ & 0.001 \\
\hline Uncertain of future earnings/health care reform & $114(81.4)$ & $287(47.4)$ & $<0.001$ & $128(39.5)$ & $273(64.8)$ & $<0.001$ \\
\hline Would choose neurosurgery again & $33(23.6)$ & $479(79.2)$ & $<0.001$ & $284(87.9)$ & $228(54.0)$ & $<0.001$ \\
\hline
\end{tabular}

istrative duties, less operating room time, and increased physical fatigue or personal health issues. Such challenges may contribute to the pessimistic and unfavorable outlook held by some neurosurgeons regarding their future career (Fig. 4). Age, by itself, was not predictive of burnout or achieving career satisfaction.

It is equally clear that neurosurgeons desire a good work/life balance. The professional perception of a good work/life balance was significant in all multivariable analyses. The long hours and hard work required of a neurosurgeon make it difficult to achieve a satisfactory balance. Numerous studies have addressed the impact of work/ home conflicts on medical professionals and have shown that physicians with career and family imbalance, recent work/home conflicts, and recent conflicts resolved in favor of work typically have higher rates of burnout. ${ }^{11,16,18}$ However, if a neurosurgeon perceives a good balance between work and personal life, then career satisfaction may be higher and risk of burnout may be lower.

Neurosurgeons, as with all health care workers, have been impacted in recent years by health care reform. As new measures of the Patient Protection and Affordable Care Act (PPACA) continue to be unveiled, uncertainty about the impact of health care reform may have adverse effects on the well-being of physicians. It has been suggested that health care reform poses an increased risk for burnout by augmenting physician workload, decreasing autonomy, and potentially disrupting physician work/life 
TABLE 5. Multivariable logistic regression analysis of 750 survey respondents

\begin{tabular}{|c|c|c|c|}
\hline Characteristic & OR & $95 \% \mathrm{Cl}$ & $p$ Value \\
\hline \multicolumn{4}{|l|}{ Burnout* $^{*}$} \\
\hline Accused of malpractice & 1.60 & $1.16-2.20$ & 0.004 \\
\hline Academic affiliation & 0.69 & $0.49-0.96$ & 0.03 \\
\hline \multicolumn{4}{|l|}{ Professional perceptions } \\
\hline $\begin{array}{l}\text { Uncertain of future earnings/ } \\
\text { health care reform }\end{array}$ & 1.96 & $1.41-2.72$ & $<0.001$ \\
\hline Challenged at work & 0.60 & $0.39-0.93$ & 0.02 \\
\hline Good work/life balance & 0.45 & $0.31-0.65$ & $<0.001$ \\
\hline $\begin{array}{l}\text { Adequate time for personal } \\
\text { development }\end{array}$ & 0.57 & $0.39-0.84$ & 0.005 \\
\hline \multicolumn{4}{|l|}{ Satisfaction $\dagger$} \\
\hline Having children & 2.4 & $1.2-4.8$ & 0.01 \\
\hline Completing $>300$ cases/yr & 1.77 & $1.03-3.03$ & 0.04 \\
\hline \multicolumn{4}{|l|}{ Professional perceptions } \\
\hline $\begin{array}{l}\text { Uncertain of future earnings/ } \\
\text { health care reform }\end{array}$ & 0.32 & $0.19-0.55$ & $<0.001$ \\
\hline Challenged at work & 4.6 & $2.9-7.4$ & $<0.001$ \\
\hline Good work/life balance & 10.0 & $4.9-20.3$ & $<0.001$ \\
\hline Burned out & 0.17 & $0.08-0.32$ & $<0.001$ \\
\hline Practiced for $>20 \mathrm{yrs}$ & 0.61 & $0.38-0.97$ & 0.04 \\
\hline
\end{tabular}

* The sex of the respondent and the perception of having a spouse who understands the need for expanded work hours did not predict outcome. The area under the receiver operating characteristic curve (AUC) $=0.89(95 \% \mathrm{Cl}$ $0.87-0.92)$.

$\dagger$ The sex of the respondent, specialty training, academic affiliation, perception of adequate time for development or a spouse who understands the need for expanded work hours did not predict outcome. The AUC $=0.74(95 \% \mathrm{Cl}$ 0.71-0.78).

balance. ${ }^{15}$ The economic implications of health care reform on a neurosurgeon's practice should also be considered as a source of anxiety. To our knowledge, no previous study has assessed this issue despite the potential for changes in the US health care system to exacerbate burnout. Our data revealed that career satisfaction among US neurosurgeons is strongly impacted by the uncertainty of future earnings and health care reform. More importantly, those who feel this uncertainty in their practice have an increased risk for burnout.

Medical malpractice was another important characteristic associated with burnout. Malpractice, which was not addressed by the PPACA, has been shown to strongly influence physician burnout, depression, and suicidal ideation among surgeons. ${ }^{3}$ Physicians who had experienced medical malpractice were more likely to score a higher burnout level in all 3 domains assessed by the MBI. ${ }^{12}$ Even though less than half of the polled neurosurgeons were involved in malpractice suits over a 5-year period (2008-2012), malpractice was still found to be associated with an increased risk of burnout and can affect patient care.

\section{Academic Versus Nonacademic Neurosurgeons}

Another intriguing aspect of the present study was our comparison of academic and nonacademic neurosurgeons. Many of the predictors of satisfaction and burnout were shared between the 2 groups. Both were more likely to be satisfied if they felt challenged at work and perceived themselves as having a good work/life balance. They were less likely to be satisfied if they were considered burned out. Academic neurosurgery had a lower rate of burnout than nonacademic neurosurgery $(47.7 \%$ vs $62.9 \%)$. These results were similar to those in previous studies in which private-practice general surgeons and oncologists had a greater burnout risk and lower career satisfaction rate.,70 Previous research has suggested that nonacademic surgeons may be at greater risk because of the higher average number of call days, the longer hours worked per week, or earnings based entirely on billing. ${ }^{37}$ In contrast to their academic colleagues, who are more likely to be salaried, nonacademic neurosurgeons in our study also had lower levels of career satisfaction when they reported uncertainty about future earnings and health care reform.

Interestingly, academic neurosurgeons were less likely to be satisfied with their careers if they had practiced as a neurosurgeon for more than 20 years. This finding suggests that while burnout may be an overall problem for nonacademic neurosurgeons, it may be a bigger problem for more senior academicians. Academia presents unique stressors, such as administrative and teaching responsibilities, tenure applications, and research requirements. These additional obligations may promote burnout as the number of years that such stressors are experienced increases and by leaving inadequate time for personal development, which, as found in our study, decreases satisfaction. It is also possible that more specialized academic neurosurgeons may be at an increased risk of burnout given the impact of repetition and decreased operative variability. ${ }^{40}$

\section{Study Limitations}

Our response rate of $24 \%$ was reasonable but on the lower end of the spectrum compared with the rates in other studies listed in Table 9. We did not offer any incentive(s) to participate as others have, although doing so may have improved our response rate. This study may suffer from selection bias whereby individuals who completed the survey may be different as a group compared with those who did not complete the survey. For example, those who currently suffer from burnout or career dissatisfaction may be less likely to take the time to complete a voluntary survey, which would underestimate the prevalence of both outcomes, or vice versa. ${ }^{23}$ Another example of selection bias relates to the results of our earlier pilot study. That study had 85 respondents, most of whom were in academics or had an academic affiliation (73\%). The senior author (P.K.) personally asked many of them to participate in the pilot study, resulting in a higher response rate (50\%). On virtually all measures, the pilot study respondents seemed to be a "happier" group than the 750 neurosurgeons in the present study (which includes the 85 in the pilot study). For example, the neurosurgeons in the pilot study had a lower burnout rate (27\% vs $57 \%$ ), higher overall satisfaction (96\% vs $81.2 \%$ ), greater work/life balance ( $74 \%$ vs 48.1 ), and greater likelihood of choosing neurosurgery again as a career (88\% vs $68.3 \%)$. While results of the present study 
TABLE 6. Univariate analysis of burnout and satisfaction among academic versus nonacademic neurosurgeons*

\begin{tabular}{|c|c|c|c|c|c|c|c|c|}
\hline \multirow[b]{3}{*}{ Characteristic } & \multicolumn{4}{|c|}{ Academic Neurosurgeons } & \multicolumn{4}{|c|}{ Nonacademic Neurosurgeons } \\
\hline & \multicolumn{2}{|c|}{ Satisfied } & \multicolumn{2}{|c|}{ Burned Out } & \multicolumn{2}{|c|}{ Satisfied } & \multicolumn{2}{|c|}{ Burned Out } \\
\hline & No & Yes & No & Yes & No & Yes & No & Yes \\
\hline No. of neurosurgeons & 41 & 267 & 161 & 147 & 100 & 342 & 164 & 278 \\
\hline \multicolumn{9}{|l|}{ Age in yrs } \\
\hline$\leq 45$ & $15(36.6)$ & $107(40.1)$ & $61(37.9)$ & $61(41.5)$ & $33(33) \dagger$ & $77(22.5) \dagger$ & $35(21.3) \dagger$ & $75(27) \dagger$ \\
\hline $46-55$ & $14(34.1)$ & $92(34.5)$ & $58(36.0)$ & $48(32.7)$ & $34(34) \dagger$ & $140(40.9) \dagger$ & $72(43.9)$ & $102(36.7)$ \\
\hline$>55$ & $12(29.3)$ & $68(25.5)$ & $42(26.1)$ & $38(25.9)$ & $33(33)$ & $125(36.5)$ & $57(34.8)$ & $101(36.3)$ \\
\hline Female & $7(17.1)$ & $38(14.2)$ & $19(11.8) \dagger$ & $26(17.7) \dagger$ & $19(19.0) \dagger$ & $30(8.8) \dagger$ & $13(7.9) \dagger$ & $36(12.9) \dagger$ \\
\hline \multicolumn{9}{|l|}{ Relationship status } \\
\hline Stable relationship/married & $38(92.7)$ & $242(90.6)$ & $147(91.3)$ & $133(90.5)$ & $90(90)$ & $313(91.5)$ & $152(92.7)$ & $251(90.3)$ \\
\hline Single & $3(7.3)$ & $25(9.4)$ & $14(8.7)$ & $14(9.5)$ & $10(10)$ & $29(8.5)$ & $12(7.3)$ & $27(9.7)$ \\
\hline Children & $33(80.5)$ & $233(87.3)$ & $144(89.4) \dagger$ & $122(83.0) \dagger$ & $83(83) \dagger$ & $318(93.0) \dagger$ & $151(92.1)$ & $250(89.9)$ \\
\hline \multicolumn{9}{|l|}{ Career duration } \\
\hline$\leq 10 \mathrm{yrs}$ & $10(24.4)$ & $74(27.7)$ & $45(48)$ & $39(26.5)$ & $22(22)$ & $88(25.7)$ & $37(22.6)$ & $73(26.3)$ \\
\hline $11-20$ yrs & $11(26.8)$ & $108(40.4)$ & $64(39.8)$ & $55(37.4)$ & $33(33.0)$ & $118(34.5)$ & $56(34.1)$ & $95(34.2)$ \\
\hline$>20$ yrs & $42(48.8) \dagger$ & $85(31.8) \dagger$ & $52(32.3)$ & $53(36.1)$ & $45(45)$ & $136(39.8)$ & $71(43.3)$ & $110(39.6)$ \\
\hline Subspecialty training & $27(65.9)$ & $206(77.2)$ & $119(73.9)$ & $114(77.6)$ & $39(39)$ & $147(43)$ & $71(43.3)$ & $115(41.4)$ \\
\hline \multicolumn{9}{|l|}{ Productivity } \\
\hline On call >10 days/mo & $11(26.8)$ & $57(21.3)$ & $34(21.1)$ & 34 (23.1) & $37(37)$ & $123(36)$ & $58(35.4)$ & $102(36.7)$ \\
\hline Performs $>300$ cases/yr & $6(14.6) \dagger$ & $73(27.3) \dagger$ & $46(28.6)$ & $33(22.4)$ & $23(23) \dagger$ & $115(33.6) \dagger$ & $54(32.9)$ & $84(30.2)$ \\
\hline Work >70 hrs/wk & $15(36.6)$ & $85(31.8)$ & $47(29.2) \dagger$ & $53(36.1) \dagger$ & $21(21)$ & $88(25.7)$ & $42(25.6)$ & $67(24.1)$ \\
\hline Accused of malpractice & $17(41.5)$ & $115(43.1)$ & $57(35.4) \dagger$ & $75(51.0) \dagger$ & $53(53)$ & $158(46.2)$ & $64(39) \dagger$ & $147(52.9) \dagger$ \\
\hline \multicolumn{9}{|l|}{ Professional perceptions } \\
\hline $\begin{array}{l}\text { Adequate time for personal } \\
\text { development }\end{array}$ & $2(4.9) \dagger$ & $125(46.8) \dagger$ & $93(57.8) \dagger$ & $34(23.1) \dagger$ & $5(5) \dagger$ & $142(41.5) \dagger$ & $81(49.4) \dagger$ & $66(23.7) \dagger$ \\
\hline Challenged at work & $23(56.1) \dagger$ & $245(91.8) \dagger$ & $148(91.9) \dagger$ & $120(81.6) \dagger$ & $39(39) \dagger$ & $273(79.8) \dagger$ & $136(82.9) \dagger$ & $176(63.3) \dagger$ \\
\hline Good work/life balance & $4(9.8) \dagger$ & $157(58.8) \dagger$ & $108(67.1) \dagger$ & $53(36.1) \dagger$ & $6(6) \dagger$ & $194(56.7) \dagger$ & $108(65.9) \dagger$ & $92(33.1) \dagger$ \\
\hline $\begin{array}{l}\text { Spouse understands extra } \\
\text { work hours }\end{array}$ & $30(73.2)$ & $201(75.3)$ & $124(77)$ & $107(72.8)$ & $61(61) \dagger$ & $259(75.7) \dagger$ & $135(82.3) \dagger$ & $185(66.5) \dagger$ \\
\hline $\begin{array}{l}\text { Uncertain of future earnings/ } \\
\text { health care reform }\end{array}$ & $26(65.0) \dagger$ & $104(39.1) \dagger$ & $50(31.3) \dagger$ & $80(54.8) \dagger$ & $88(88) \dagger$ & $183(54) \dagger$ & $78(47.6) \dagger$ & $193(70.2) \dagger$ \\
\hline
\end{tabular}

* Values expressed as number (\%).

$\dagger$ Included in multivariable logistic regression due to $p$ value $<0.2$.

are internally valid, the results may not be completely generalizable to surgeons who did not complete the survey. Nonetheless, we think that the 750 survey respondents in the current study are probably a more representative sample of US neurosurgeons than the 85 participants in the pilot study, and thus the full sample provides a more accurate assessment of burnout and job satisfaction.

Neurosurgeons are constantly asked to participate in various surveys, which leads to apathy or "survey fatigue," making it difficult to conduct such studies. The results may not be applicable to neurosurgeons outside the US, although it is reasonable to assume that there is some degree of universality in terms of sources of stress and satisfaction among all neurosurgeons, regardless of practice location. As with any survey study, some of the questions may not have been clearly understood by all participants. For example, the divorce rate of the neurosurgeons sampled was only $9.1 \%$. This is significantly lower than previously published rates, suggesting that miscommunication probably occurred at some level of survey administration. ${ }^{16,37}$ Shortening the survey was necessary to improve our response rate; however, doing so resulted in less information in comparison with that in the pilot study. Nonetheless, we believe that the shortened survey was able to capture the important aspects of a career that have direct relevance on satisfaction, stress, and burnout.

\section{Future Studies}

To safely and reliably provide for the needs of the increasing patient population in the US, it is essential that individual and organizational interventions be created to diminish the potency of potential stressors in all medical specialties that can lead to unhealthy levels of stress and burnout. ${ }^{29,41,42}$ Such programs could be tailored to practice types (for example, academic vs private vs hospital based) based on research that would further clarify predictors of 
TABLE 7. Multivariable logistic regression analysis of 308 academic neurosurgeons

\begin{tabular}{|c|c|c|c|}
\hline Characteristic & OR & $95 \% \mathrm{Cl}$ & $\mathrm{p}$ Value \\
\hline \multicolumn{4}{|l|}{ Burnout* } \\
\hline \multicolumn{4}{|l|}{ Professional perceptions } \\
\hline $\begin{array}{l}\text { Uncertain of future earnings/ } \\
\text { health care reform }\end{array}$ & 2.03 & $1.23-3.34$ & 0.005 \\
\hline $\begin{array}{l}\text { Adequate time for personal } \\
\text { development }\end{array}$ & 0.37 & $0.20-0.68$ & 0.001 \\
\hline Good work/life balance & 0.55 & $0.30-0.99$ & 0.04 \\
\hline \multicolumn{4}{|l|}{ Satisfaction† } \\
\hline \multicolumn{4}{|l|}{ Professional perceptions } \\
\hline Good work/life balance & 7.47 & $2.4-23.7$ & 0.001 \\
\hline Challenged at work & 5.68 & $2.3-14.0$ & $<0.001$ \\
\hline Practiced $>20$ yrs & 0.34 & $0.15-0.78$ & 0.01 \\
\hline Burned out & 0.074 & $0.02-0.26$ & $<0.001$ \\
\hline \multicolumn{4}{|c|}{$\begin{array}{l}\text { * The sex of the respondent, having children, working more than } 70 \text { hours/ } \\
\text { week, being accused of malpractice, and being challenged at work did not } \\
\text { predict outcome. The AUC }=0.73(95 \% \mathrm{Cl} 0.67-0.78) \text {. } \\
\dagger \text { Caseload, uncertainty about future earning potential due to health care re- } \\
\text { form, the perception of having adequate time for personal growth, and subspe- } \\
\text { cialty training did not predict outcome. The AUC }=0.89(95 \% \mathrm{Cl} 0.85-0.94) \text {. }\end{array}$} \\
\hline
\end{tabular}

TABLE 8. Multivariable logistic regression analysis of 442 nonacademic neurosurgeons

\begin{tabular}{|c|c|c|c|}
\hline Characteristic & OR & $95 \% \mathrm{Cl}$ & $\mathrm{p}$ Value \\
\hline \multicolumn{4}{|l|}{ Burnout* } \\
\hline Accused of malpractice & 1.69 & $1.11-2.58$ & 0.15 \\
\hline \multicolumn{4}{|l|}{ Professional perceptions } \\
\hline Good work/life balance & 0.34 & $0.22-0.52$ & $<0.001$ \\
\hline Challenged at work & 0.49 & $0.29-0.81$ & 0.005 \\
\hline $\begin{array}{l}\text { Uncertain of future earnings/ } \\
\text { health care reform }\end{array}$ & 1.96 & $1.28-3.02$ & 0.002 \\
\hline \multicolumn{4}{|l|}{ Satisfaction† } \\
\hline Having children & 4.75 & $1.91-11.82$ & 0.001 \\
\hline \multicolumn{4}{|l|}{ Professional perceptions } \\
\hline Good work/life balance & 11.99 & $4.80-29.93$ & $<0.001$ \\
\hline Challenged at work & 4.70 & $2.63-8.37$ & $<0.001$ \\
\hline $\begin{array}{l}\text { Uncertain of future earnings/ } \\
\text { health care reform }\end{array}$ & 0.19 & $0.86-0.41$ & $<0.001$ \\
\hline Burned out & 0.23 & $0.10-0.53$ & 0.001 \\
\hline \multicolumn{4}{|c|}{$\begin{array}{l}\text { * The sex of the respondent, working more than } 70 \text { hours/week, an age }< \\
46 \text { years, the perception of having adequate time for personal growth, and } \\
\text { the perception of having a spouse who understands extra work hours did not } \\
\text { predict outcome. The AUC }=0.73 \text { ( } 95 \% \mathrm{Cl} 0.68-0.78) \text {. } \\
\dagger \text { Caseload, the perception of having adequate time for personal growth, an } \\
\text { age }<46 \text { years, the sex of the respondent, and the perception of having a } \\
\text { spouse who understands the need for expanded work hours did not predict } \\
\text { outcome. The AUC }=0.88 \text { ( } 95 \% \mathrm{Cl} 0.85-0.91 \text { ). }\end{array}$} \\
\hline
\end{tabular}

job satisfaction and burnout. Some researchers have already begun work on programs to reduce stress and burnout. ${ }^{24,46}$ An intervention involving facilitated physician discussion groups around mindfulness, reflection, shared experience, and small-group learning has shown increased
TABLE 9. Burnout rates for various surgical and nonsurgical specialties

\begin{tabular}{|c|c|c|}
\hline Specialty & $\begin{array}{l}\text { Burnout } \\
\text { Rate (\%) }\end{array}$ & $\begin{array}{c}\text { No. of Participants } \\
\text { (Response Rate) }\end{array}$ \\
\hline Neurosurgery (current) & 57 & $783(24 \%)$ \\
\hline Neurosurgery (pilot) ${ }^{23}$ & 27 & $85(50 \%)$ \\
\hline Plastic surgery ${ }^{45}$ & 29 & $505(71 \%)^{*}$ \\
\hline Orthopedic surgery ${ }^{33}$ & 28 & $264(24 \%)$ \\
\hline Surgical oncology 25 & 28 & $549(36 \%)$ \\
\hline $\begin{array}{l}\text { British colorectal and vascular } \\
\text { surgeons }{ }^{44}\end{array}$ & 32 & $501(59 \%) \dagger$ \\
\hline Transplant surgery ${ }^{8}$ & 38 & $259(35 \%)$ \\
\hline American surgeons ${ }^{37}$ & 40 & $7905(32 \%)$ \\
\hline Clinical oncology 40 & 45 & $1490(50 \%) \ddagger$ \\
\hline NICU physicians ${ }^{32}$ & 15 & $\begin{array}{l}204 \text { (not } \\
\text { given)§ }\end{array}$ \\
\hline Switzerland ICU physicians ${ }^{31}$ & 31 & $465(69 \%)$ \\
\hline Italian psychiatrists ${ }^{10}$ & 49 & $81(70 \%)$ \\
\hline Emergency medicine ${ }^{26}$ & 32 & $193(43 \%)$ \\
\hline $\begin{array}{l}\text { New Zealand public hospital } \\
\text { radiologists }^{27}\end{array}$ & 23 & $136(51 \%)$ \\
\hline Ophthalmology chairs ${ }^{13}$ & 9 & $101(77 \%)$ \\
\hline Infectious disease ${ }^{14}$ & 44 & $1840(46 \%)$ \\
\hline
\end{tabular}

ICU = intensive care unit; NICU = neonatal ICU.

* Participants were offered a cash gift for completion.

$\dagger$ Response rate was $55.6 \%$ for colorectal surgeons and $62.3 \%$ for vascular surgeons.

‡ Participants were offered a free American Society of Clinical Oncology educational product for completion.

$\S$ Response rate only given for entire study population, of which NICU physicians accounted for only $10 \%$.

empowerment and engagement at work, decreased rates of depersonalization, and decreased overall burnout among participating physicians. ${ }^{46}$ Another intervention that offered an educational course on mindfulness meditation, self-awareness, and meaningful clinical narratives was shown to improve scores for mindfulness, burnout, depersonalization, personal accomplishment, and empathy. ${ }^{24}$ Finally, it would be interesting to repeat this study in the future to ascertain the full impact of health care reform.

\section{Conclusions}

Neurosurgery is a rewarding career choice, but there are many challenges and stressors that can lead to lower levels of satisfaction and dangerously increased levels of burnout. This may translate into negative medical experiences for surgeons, patients, and their families. Factors independently associated with burnout and career satisfaction were identified for all study participants, including academic and nonacademic neurosurgeons. Neurosurgeons desire intellectual and technical challenges and a positive balance between work and life. Uncertainty regarding future earnings and health care reform are major sources of discontent and burnout. We hope these results will generate discussion, raise awareness, stimulate further studies, 
and lead to programs designed to mitigate excessive stress and burnout within neurosurgery.

\section{Acknowledgment}

We thank Andrew J. Gienapp for technical and copy editing, preparation of the manuscript and figures for publishing, and publication assistance with this manuscript.

\section{References}

1. Balch CM, Copeland E: Stress and burnout among surgical oncologists: a call for personal wellness and a supportive workplace environment. Ann Surg Oncol 14:3029-3032, 2007

2. Balch CM, Freischlag JA, Shanafelt TD: Stress and burnout among surgeons: understanding and managing the syndrome and avoiding the adverse consequences. Arch Surg 144:371376, 2009

3. Balch CM, Oreskovich MR, Dyrbye LN, Colaiano JM, Satele DV, Sloan JA, et al: Personal consequences of malpractice lawsuits on American surgeons. J Am Coll Surg 213:657667, 2011

4. Balch CM, Shanafelt TD: Burnout among surgeons: whether specialty makes a difference. Arch Surg 146:385-386, 2011

5. Balch CM, Shanafelt TD, Dyrbye L, Sloan JA, Russell TR, Bechamps GJ, et al: Surgeon distress as calibrated by hours worked and nights on call. J Am Coll Surg 211:609-619, 2010

6. Balch CM, Shanafelt TD, Sloan J, Satele DV, Kuerer HM: Burnout and career satisfaction among surgical oncologists compared with other surgical specialties. Ann Surg Oncol 18:16-25, 2011

7. Balch CM, Shanafelt TD, Sloan JA, Satele DV, Freischlag JA: Distress and career satisfaction among 14 surgical specialties, comparing academic and private practice settings. Ann Surg 254:558-568, 2011

8. Bertges Yost W, Eshelman A, Raoufi M, Abouljoud MS: A national study of burnout among American transplant surgeons. Transplant Proc 37:1399-1401, 2005

9. Bittner JG IV, Khan Z, Babu M, Hamed O: Stress, burnout, and maladaptive coping: strategies for surgeon well-being. Bull Am Coll Surg 96:17-22, 2011

10. Bressi C, Porcellana M, Gambini O, Madia L, Muffatti R, Peirone A, et al: Burnout among psychiatrists in Milan: a multicenter survey. Psychiatr Serv 60:985-988, 2009

11. Campbell DA Jr, Sonnad SS, Eckhauser FE, Campbell KK, Greenfield LJ: Burnout among American surgeons. Surgery 130:696-705, 2001

12. Chen KY, Yang CM, Lien CH, Chiou HY, Lin MR, Chang HR, et al: Burnout, job satisfaction, and medical malpractice among physicians. Int J Med Sci 10:1471-1478, 2013

13. Cruz OA, Pole CJ, Thomas SM: Burnout in chairs of academic departments of ophthalmology. Ophthalmology 114:2350-2355, 2007

14. Deckard GJ, Hicks LL, Hamory BH: The occurrence and distribution of burnout among infectious diseases physicians. J Infect Dis 165:224-228, 1992

15. Dyrbye LN, Shanafelt TD: Physician burnout: a potential threat to successful health care reform. JAMA 305:20092010, 2011

16. Dyrbye LN, Shanafelt TD, Balch CM, Satele D, Sloan J, Freischlag J: Relationship between work-home conflicts and burnout among American surgeons: a comparison by sex. Arch Surg 146:211-217, 2011

17. Dyrbye LN, Varkey P, Boone SL, Satele DV, Sloan JA, Shanafelt TD: Physician satisfaction and burnout at different career stages. Mayo Clin Proc 88:1358-1367, 2013

18. Dyrbye LN, West CP, Satele D, Sloan JA, Shanafelt TD:
Work/home conflict and burnout among academic internal medicine physicians. Arch Intern Med 171:1207-1209, 2011

19. Firth-Cozens J, Greenhalgh J: Doctors' perceptions of the links between stress and lowered clinical care. Soc Sci Med 44:1017-1022, 1997

20. Haas JS, Cook EF, Puopolo AL, Burstin HR, Cleary PD, Brennan TA: Is the professional satisfaction of general internists associated with patient satisfaction? J Gen Intern Med 15:122-128, 2000

21. Jones JW, Barge BN, Steffy BD, Fay LM, Kunz LK, Wuebker LJ: Stress and medical malpractice: organizational risk assessment and intervention. J Appl Psychol 73:727-735, 1988

22. Kent GG, Johnson AG: Conflicting demands in surgical practice. Ann R Coll Surg Engl 77 (5 Suppl):235-238, 1995

23. Klimo P Jr, DeCuypere M, Ragel BT, McCartney S, Couldwell WT, Boop FA: Career satisfaction and burnout among U.S. neurosurgeons: a feasibility and pilot study. World Neurosurg 80:e59-e68, 2013

24. Krasner MS, Epstein RM, Beckman H, Suchman AL, Chapman B, Mooney CJ, et al: Association of an educational program in mindful communication with burnout, empathy, and attitudes among primary care physicians. JAMA 302:12841293, 2009

25. Kuerer HM, Eberlein TJ, Pollock RE, Huschka M, Baile WF, Morrow M, et al: Career satisfaction, practice patterns and burnout among surgical oncologists: report on the quality of life of members of the Society of Surgical Oncology. Ann Surg Oncol 14:3043-3053, 2007

26. Kuhn G, Goldberg R, Compton S: Tolerance for uncertainty, burnout, and satisfaction with the career of emergency medicine. Ann Emerg Med 54:106-113.e6, 2009

27. Lim RC, Pinto C: Work stress, satisfaction and burnout in New Zealand radiologists: comparison of public hospital and private practice in New Zealand. J Med Imaging Radiat Oncol 53:194-199, 2009

28. Linn LS, Brook RH, Clark VA, Davies AR, Fink A, Kosecoff $\mathrm{J}$ : Physician and patient satisfaction as factors related to the organization of internal medicine group practices. Med Care 23:1171-1178, 1985

29. Linzer M: Preventing burnout in academic medicine. Arch Intern Med 169:927-928, 2009

30. Maslach C, Jackson SE, Leiter MP: Maslach Burnout Inventory Manual, ed 3. Palo Alto, CA: Consulting Psychologists Press, 1996

31. Merlani P, Verdon M, Businger A, Domenighetti G, Pargger H, Ricou B: Burnout in ICU caregivers: a multicenter study of factors associated to centers. Am J Respir Crit Care Med 184:1140-1146, 2011

32. Profit J, Sharek PJ, Amspoker AB, Kowalkowski MA, Nisbet CC, Thomas EJ, et al: Burnout in the NICU setting and its relation to safety culture. BMJ Qual Saf 23:806-813, 2014

33. Sargent MC, Sotile W, Sotile MO, Rubash H, Barrack RL: Quality of life during orthopaedic training and academic practice. Part 1: orthopaedic surgery residents and faculty. J Bone Joint Surg Am 91:2395-2405, 2009

34. Shanafelt T, Dyrbye L: Oncologist burnout: causes, consequences, and responses. J Clin Oncol 30:1235-1241, 2012

35. Shanafelt T, Sloan J, Satele D, Balch C: Why do surgeons consider leaving practice? J Am Coll Surg 212:421-422, 2011

36. Shanafelt TD, Balch CM, Bechamps G, Russell T, Dyrbye L, Satele D, et al: Burnout and medical errors among American surgeons. Ann Surg 251:995-1000, 2010

37. Shanafelt TD, Balch CM, Bechamps GJ, Russell T, Dyrbye L, Satele D, et al: Burnout and career satisfaction among American surgeons. Ann Surg 250:463-471, 2009

38. Shanafelt TD, Boone S, Tan L, Dyrbye LN, Sotile W, Satele $\mathrm{D}$, et al: Burnout and satisfaction with work-life balance among US physicians relative to the general US population. Arch Intern Med 172:1377-1385, 2012 
39. Shanafelt TD, Bradley KA, Wipf JE, Back AL: Burnout and self-reported patient care in an internal medicine residency program. Ann Intern Med 136:358-367, 2002

40. Shanafelt TD, Gradishar WJ, Kosty M, Satele D, Chew H, Horn L, et al: Burnout and career satisfaction among US oncologists. J Clin Oncol 32:678-686, 2014

41. Shanafelt TD, Kaups KL, Nelson H, Satele DV, Sloan JA, Oreskovich MR, et al: An interactive individualized intervention to promote behavioral change to increase personal wellbeing in US surgeons. Ann Surg 259:82-88, 2014

42. Shanafelt TD, Oreskovich MR, Dyrbye LN, Satele DV, Hanks JB, Sloan JA, et al: Avoiding burnout: the personal health habits and wellness practices of US surgeons. Ann Surg 255:625-633, 2012

43. Shanafelt TD, Raymond M, Kosty M, Satele D, Horn L, Pippen J, et al: Satisfaction with work-life balance and the career and retirement plans of US oncologists. J Clin Oncol 32:1127-1135, 2014

44. Sharma A, Sharp DM, Walker LG, Monson JR: Stress and burnout in colorectal and vascular surgical consultants working in the UK National Health Service. Psychooncology 17:570-576, 2008

45. Streu R, Hansen J, Abrahamse P, Alderman AK: Professional burnout among US plastic surgeons: results of a national survey. Ann Plast Surg 72:346-350, 2014

46. West CP, Dyrbye LN, Rabatin JT, Call TG, Davidson JH, Multari A, et al: Intervention to promote physician wellbeing, job satisfaction, and professionalism: a randomized clinical trial. JAMA Intern Med 174:527-533, 2014

47. West CP, Huschka MM, Novotny PJ, Sloan JA, Kolars JC, Habermann TM, et al: Association of perceived medical errors with resident distress and empathy: a prospective longitudinal study. JAMA 296:1071-1078, 2006

48. Williams ES, Manwell LB, Konrad TR, Linzer M: The relationship of organizational culture, stress, satisfaction, and burnout with physician-reported error and suboptimal patient care: results from the MEMO study. Health Care Manage Rev 32:203-212, 2007

\section{Author Contributions}

Conception and design: Klimo, Ragel, McCartney, DeCuypere, Cheng, Boop. Acquisition of data: McCartney. Analysis and interpretation of data: Klimo. Drafting the article: Klimo, McAbee. Critically revising the article: Klimo, McAbee. Reviewed submitted version of manuscript: Klimo, McAbee, Jones, Michael, DeCuypere, Boop. Approved the final version of the manuscript on behalf of all authors: Klimo. Statistical analysis: Jones. Administrative/technical/material support: McCartney, Cheng. Study supervision: Klimo.

\section{Correspondence}

Paul Klimo Jr., Department of Neurosurgery, Le Bonheur Children's Hospital, 50 N. Dunlap St., Memphis, TN 38103. email:pklimo@semmes-murphey.com.

\section{Appendix}

Neurosurgeon Career and Lifestyle Satisfaction Survey

\section{Section 1: Demographic Questions}

\begin{tabular}{|c|c|c|}
\hline Question & $\begin{array}{l}\text { Survey Response } \\
\text { Categories }\end{array}$ & $\begin{array}{l}\text { Categories } \\
\text { Analyzed* }^{*}\end{array}$ \\
\hline \multirow[t]{3}{*}{$\begin{array}{l}\text { What is your age } \\
\text { (years)? }\end{array}$} & $\begin{array}{l}<40 \\
41-45\end{array}$ & $<46$ \\
\hline & $\begin{array}{l}46-50 \\
51-55\end{array}$ & $46-55$ \\
\hline & $\begin{array}{l}56-60 \\
61-65 \\
>65\end{array}$ & $>55$ \\
\hline What is your gender? & $\begin{array}{l}\text { Male } \\
\text { Female }\end{array}$ & No change \\
\hline \multirow[t]{2}{*}{$\begin{array}{l}\text { What is your marital } \\
\text { status? }\end{array}$} & $\begin{array}{l}\text { Married } \\
\text { Stable partner } \\
\text { Divorced and remarried }\end{array}$ & $\begin{array}{l}\text { Currently } \\
\text { married or } \\
\text { in a stable } \\
\text { relationship }\end{array}$ \\
\hline & $\begin{array}{l}\text { Separated } \\
\text { Divorced } \\
\text { Single }\end{array}$ & $\begin{array}{l}\text { Currently } \\
\text { single }\end{array}$ \\
\hline \multirow[t]{2}{*}{$\begin{array}{l}\text { What is your practice } \\
\text { type? }\end{array}$} & $\begin{array}{l}\text { Group } \\
\text { University } \\
\text { Private with academic } \\
\quad \text { affiliation } \\
\text { Solo }\end{array}$ & No change \\
\hline & $\begin{array}{l}\text { Health management } \\
\text { organization } \\
\text { VA/government hospital } \\
\text { City/county hospital } \\
\text { Other }\end{array}$ & Other \\
\hline \multirow{3}{*}{$\begin{array}{l}\text { How many years } \\
\text { have you been in } \\
\text { practice? }\end{array}$} & $\begin{array}{l}<5 \\
5-10\end{array}$ & $\leq 10$ \\
\hline & $\begin{array}{l}11-15 \\
16-20\end{array}$ & $11-20$ \\
\hline & $\begin{array}{l}21-25 \\
>25\end{array}$ & $>20$ \\
\hline \multirow[t]{2}{*}{$\begin{array}{l}\text { Have you received } \\
\text { formal subspe- } \\
\text { cialty training? }\end{array}$} & $\begin{array}{l}\text { None } \\
\text { Cerebrovascular } \\
\text { Functional/stereotactic } \\
\text { Pediatrics } \\
\text { Spine } \\
\text { Skull base }\end{array}$ & No change \\
\hline & $\begin{array}{l}\text { Endovascular } \\
\text { Neurotrauma } \\
\text { Other }\end{array}$ & Other \\
\hline \multirow[t]{2}{*}{$\begin{array}{l}\text { On average, how } \\
\text { many hours do } \\
\text { you work per } \\
\text { week? }\end{array}$} & $\begin{array}{l}<30 \\
30-40 \\
41-50 \\
51-60 \\
61-70\end{array}$ & $\leq 70$ \\
\hline & $\begin{array}{l}71-80 \\
>80\end{array}$ & $>70$ \\
\hline
\end{tabular}


Section 1: Demographic Questions (continued)

\begin{tabular}{|c|c|c|}
\hline Question & $\begin{array}{l}\text { Survey Response } \\
\text { Categories }\end{array}$ & $\begin{array}{l}\text { Categories } \\
\text { Analyzed }^{*}\end{array}$ \\
\hline \multirow[t]{2}{*}{$\begin{array}{l}\text { How many days of } \\
\text { call do you take } \\
\text { per month? }\end{array}$} & $\begin{array}{l}<3 \\
3-5 \\
6-10\end{array}$ & $<10$ \\
\hline & $>10$ & No change \\
\hline \multirow[t]{2}{*}{$\begin{array}{l}\text { On average, how } \\
\text { many operative } \\
\text { cases do you per- } \\
\text { form annually? }\end{array}$} & $\begin{array}{l}<100 \\
100-150 \\
151-200 \\
201-250 \\
251-300\end{array}$ & $\leq 300$ \\
\hline & $\begin{array}{l}301-350 \\
350-400 \\
>400\end{array}$ & $>300$ \\
\hline \multirow{2}{*}{$\begin{array}{l}\text { Over the last } 5 \text { years, } \\
\text { how many times } \\
\text { have you been } \\
\text { named in a mal- } \\
\text { practice lawsuit? }\end{array}$} & None & No change \\
\hline & $1-5$ & At least once \\
\hline \multicolumn{3}{|c|}{$\begin{array}{l}\text { VA = Veterans Affairs. } \\
\text { * Survey response categories were combined into categories for the purposes } \\
\text { of statistical analysis based on previously published literature and the number } \\
\text { of responses by persons completing the survey. All categories were deter- } \\
\text { mined prior to completion of any statistical analysis. }\end{array}$} \\
\hline
\end{tabular}

Section 2: Professional Stressors

\begin{tabular}{|c|c|c|}
\hline \multirow{2}{*}{$\begin{array}{l}\text { Question } \\
\text { Factors }\end{array}$} & \multicolumn{2}{|c|}{$\begin{array}{c}\text { To what extent have the following factors affected you in } \\
\text { your practice over the last } 12-24 \text { months? }\end{array}$} \\
\hline & Too much call & Sexual harassment \\
\hline & Inadequate research time & Malpractice issues \\
\hline & $\begin{array}{l}\text { Inadequate administration } \\
\text { time }\end{array}$ & Too many cases \\
\hline & Inadequate teaching time & Too few cases \\
\hline & Low salary/income & Too little vacation time \\
\hline & $\begin{array}{l}\text { Chairman's/Senior Part- } \\
\text { ner's demands }\end{array}$ & $\begin{array}{l}\text { Surgery-related complica- } \\
\text { tions }\end{array}$ \\
\hline & $\begin{array}{l}\text { Hostile or difficult work } \\
\text { environment }\end{array}$ & Loss of coworker/faculty \\
\hline & Tenure/promotion issues & $\begin{array}{l}\text { Uncertainty of future earn- } \\
\text { ings/health care reform* }\end{array}$ \\
\hline Answers & $\begin{array}{l}\text { Not at all } \\
\text { Small amount } \\
\text { Moderate amount }\end{array}$ & $\begin{array}{l}\text { Large amount } \\
\text { Extreme amount } \\
\text { Not applicable }\end{array}$ \\
\hline
\end{tabular}

* Respondents selecting "large amount" or "extreme amount" were classified on a dichotomous scale as having the factor of interest (yes) for the purposes of statistical analysis.

\section{Section 3: Professional Satisfaction}

\begin{tabular}{|c|c|c|}
\hline Question & $\begin{array}{r}\text { In relation to your practice, ho } \\
\text { factors liste }\end{array}$ & $\begin{array}{l}\text { w satisfied are you with the } \\
\text { d below? }\end{array}$ \\
\hline \multirow[t]{4}{*}{ Factors } & $\begin{array}{l}\text { Overall career as a neuro- } \\
\text { surgeon* }\end{array}$ & $\begin{array}{l}\text { Intellectually challenged } \\
\text { at work* }\end{array}$ \\
\hline & $\begin{array}{l}\text { Balance between profes- } \\
\text { sional and personal life* }\end{array}$ & Neurosurgical colleagues \\
\hline & $\begin{array}{l}\text { Meeting your career expec- } \\
\text { tations/goals }\end{array}$ & Location of practice \\
\hline & $\begin{array}{l}\text { Time for personal growth/ } \\
\text { development* }\end{array}$ & Salary/income \\
\hline Answers & $\begin{array}{l}\text { Very satisfied } \\
\text { Somewhat satisfied } \\
\text { Neutral }\end{array}$ & $\begin{array}{l}\text { Somewhat dissatisfied } \\
\text { Very dissatisfied } \\
\text { Not applicable }\end{array}$ \\
\hline
\end{tabular}

* Respondents selecting "very satisfied" or "somewhat satisfied" were classified on a dichotomous scale as having the factor of interest (yes) for the purposes of statistical analysis.

\section{Section 4: Quality of Life}

\begin{tabular}{|c|c|c|}
\hline Question & \multicolumn{2}{|c|}{ Please respond to the following statements below: } \\
\hline \multirow[t]{4}{*}{ Factors } & $\begin{array}{l}\text { My spouse/partner under- } \\
\text { stands when I have to } \\
\text { work extra hours }\end{array}$ & $\begin{array}{l}\text { My practice should } \\
\text { improve its reimburse- } \\
\text { ment }\end{array}$ \\
\hline & $\begin{array}{l}\text { My practice should mini- } \\
\text { mize emergency call }\end{array}$ & $\begin{array}{l}\text { My practice should work } \\
\text { harder to diminish } \\
\text { litigation }\end{array}$ \\
\hline & $\begin{array}{l}\text { My practice has an unfair } \\
\text { call schedule }\end{array}$ & $\begin{array}{l}\text { I would recommend neu- } \\
\text { rosurgery to my child } \\
\text { as a career }\end{array}$ \\
\hline & \multicolumn{2}{|c|}{$\begin{array}{l}\text { My practice/program should increase the number of } \\
\text { residents/physician extenders }\end{array}$} \\
\hline \multirow[t]{3}{*}{ Answers } & Strongly agree & Disagree \\
\hline & Agree & Strongly disagree \\
\hline & Neutral & Not applicable \\
\hline
\end{tabular}


Section 5: Maslach Burnout Inventory*

\begin{tabular}{|c|c|c|}
\hline Question & \multicolumn{2}{|c|}{ How often do you experience the following? } \\
\hline \multirow[t]{3}{*}{ Factors } & \multicolumn{2}{|c|}{ 1. I feel emotionally drained from my work } \\
\hline & \multicolumn{2}{|c|}{ 2. I feel used up at the end of the day } \\
\hline & \multicolumn{2}{|c|}{$\begin{array}{l}\text { 3. I feel fatigued when I get up in the morning to face } \\
\text { another workday }\end{array}$} \\
\hline Answers & $\begin{array}{l}\text { Never } \\
\text { Few times a year } \\
\text { Monthly } \\
\text { Few times a month }\end{array}$ & $\begin{array}{l}\text { Weekly } \\
\text { Few times a week } \\
\text { Daily }\end{array}$ \\
\hline
\end{tabular}

* Sample of first 3 questions; the inventory consists of 22 questions total.

\section{Section 6: General Questions}

\begin{tabular}{cl}
\hline \multicolumn{1}{c}{ Question } & \multicolumn{1}{c}{ Answer } \\
\hline $\begin{array}{c}\text { If you were a 4th year medical student, } \\
\text { would you still choose to pursue neuro- }\end{array}$ & Yes \\
surgery as a career? & No \\
\hline How likely do you feel that your profes- & Likely \\
sional life will improve?* & Somewhat likely \\
& Not sure \\
& Somewhat unlikely \\
& Unlikely \\
\hline How likely do you feel that your profes- & Likely \\
sional life will worsen?* & Somewhat likely \\
& Not sure \\
& Somewhat unlikely \\
Please provide the most rewarding aspect & Unlikely \\
of your career. & Written answer \\
\hline Please provide the most frustrating & Written answer \\
aspect of your career. & \\
\hline
\end{tabular}

* Respondents selecting "likely" or "somewhat likely" were classified on a dichotomous scale as having the factor of interest (yes) for the purposes of statistical analysis. 